\title{
Ki Hadjar Dewantara Leadership Concept Development as a Sustainable Shareholder Value Driving Force
}

\author{
Satriyo NUGROHO ${ }^{1}$, Umar NIMRAN $^{2}$, Mochammad Al MUSADIEQ ${ }^{3}$, Solimun SOLIMUN ${ }^{4}$ \\ Received: July 03, 2020 Revised: September 19, 2020 Accepted: October 05, 2020
}

\begin{abstract}
This research examined the effect of KHD Leadership toward Sustainable Shareholder Value and mediated by IT \& Business Strategy Alignement and Integrated Supply Chain Management. Therefore, with this research, it is expected to be able to develop the KHD Leadership in State-owned enterprises' (SOEs) Indonesian. The population in this study were all echelon 1, 2, and 3 employees in the PT Pupuk Kalimantan Timur, PT Pupuk Petrokimia Gresik, PT Pupuk Sriwidjaja Palembang, PT Pupuk Kujang Cikampek, PT Pupuk Iskandar Muda, as many as $\mathrm{N}=1002$ people. The appropriate sampling technique used is Proportional Stratified Random Sampling ( $\mathrm{n}=300$ employees). The statistical analysis used is SEM-WarpPLS method. IT \& Business Strategy Alignement and Integrated Supply Chain Management significant and positive on Sustainable Shareholder Value. IT \& Business Strategy Alignment and IT Integrated Suppy Chain Management is a mediating variable between the influence of KHD Leadership on Sustainable Shareholder Value. Novelty in this research is the development of $\mathrm{Ki}$ Hadjar Dewantara Leadership as the development of the concept of Javanese leadership that grows inherent in Indonesian society, especially Javanese society and is believed to be applicable in business and industrial organizations in Indonesia, of course it can also be implemented in Pupuk Indonesia Holding Company.
\end{abstract}

Keywords: Ki Hadjar Dewantara Leadership, Business Strategy, Integrated Supply Chain Management, Shareholder Value

JEL Classification Code: M10, M15, M30

\section{Introduction}

Leadership is a process by which individuals influence groups to achieve common goals (Northouse, 2003). Gibson et al. (2000) stated Leaders are agents of change, individuals whose actions affect other people instead of the other way around. Sweeney and McFarlin (2002) described an example of the notion of leadership as behavior. Leadership involves a set of interpersonal influence processes. The processes are

${ }^{1}$ First Author and Corresponding Author. Faculty of Administrative Sciences, Brawijaya University, Indonesia [Postal Address: Veteran Street, Malang, East Java, 65145, Indonesia]

Email: satriyo_nugroho@student.ub.ac.id

${ }^{2}$ Faculty of Administrative Sciences, Brawijaya University, Indonesia. Email: umar.nimran.ub@gmail.com

${ }^{3}$ Faculty of Administrative Sciences, Brawijaya University, Indonesia. Email: al.musadieq018@gmail.com

${ }^{4}$ Faculty of Administrative Sciences, Brawijaya University, Indonesia. Email: Solimun@ub.ac.id

(c) Copyright: The Author(s)

This is an Open Access article distributed under the terms of the Creative Commons Attribution Non-Commercial License (https://creativecommons.org/licenses/by-nc/4.0/) which permits unrestricted non-commercial use, distribution, and reproduction in any medium, provided the original work is properly cited. aimed at motivating subordinates, creating a vision for the future, and developing strategies to achieve goals.

Management challenges in the 21st Century are related to "knowledge workers", which require new management paradigms, strategies, change leadership, information challenges, knowledge-based employee productivity, and self-management skills (Drucker, 1998). Based on various opinions of experts, future leadership is a leader adaptive to challenges, adhere regulations, cares for employees, maintains discipline and leadership. In addition, leaders prepare solutions to solve future challenges.

There were various leadership concepts suggested by organizational behavior experts. The leadership concepts were transactional, transformational, situational, and other leadership styles. However, the Republic of Indonesia leadership style adopts the Ki Hadjar Dewantara Leadership (KHD Leadership). The concept of Ki Hadjar Dewantara leadership philosophy originated from the well-known Javanese proverb: Ng Ngarsa Sung Tuladha (set example in the front), Ing Madya Mangun Karsa (inspires enthusiasm in the middle), and Tut Wuri Handayani (encourages from behind) (Kusmanto \& Widodo, 2016; Marce \& Purbonuswanto, 2019; Marliani \& Djadjuli, 2019). 
In modern leadership theory, Robert K. Greenleaf (1970) states a leadership concept that stems from natural feeling to serve others, prioritizes the needs of followers, works with others to solve problems, and helps others in achieving common goals. The essence of this leadership model is serving those who are led. For instance, employees, subordinates, customers, or the wider community. Greenleaf stated that service-oriented leaders act with integrity and develop trust relationships. Furthermore, the leaders help others to learn, grow, and develop ability to lead themselves.

Combined with the KHD Leadership concept, the servant leadership model is similar to Ing Madyo Mangun Karso (inspires enthusiasm in the middle). Based on the description above, the KHD concept is believed to possess complete concept of servant leadership concept. It possesses more leadership concepts, namely Ing Ngarso Sung Tulodo (sets example in the front) and Tut Wuri Handayani (encourages from behind). Leaders must understand the conditions of the millennial generation. It could be conducted by giving the subordinates the freedom to express and be creative. However, the leader must supervise and determine the target. This is in line with Tut Wuri Handayani. It indicates that KHD Leadership is universal and has been widely implemented in foreign companies. KHD Leadership is not merely a leadership requirement in Indonesia. The leaders must be able to demonstrate and apply KHD value to achieve company/organization goals.

The increasing business competition encourages a changing and complex environment. In turn, leaders endeavor to create a responsive company supply chain (SC). The application of SCM is expected to anticipate or manage these uncertainties. Therefore, companies need to employ Integrated Supply Chain Management (ISCM). Adequate information technology is crucial in implementing ISCM. Information technology supports internal operations of the organization and collaboration between companies in the supply chain. This indicates the importance of communication and the application of Information Technology. Business strategic planning requires the involvement of top management and IT strategy planning.

PT Pupuk Indonesia Holding Company, as a State-Owned Enterprise (BUMN), is required to be able to manage threats, opportunities, and other problems in a manner that supports business sustainability and ensure the sustainability of value creation (Sustainable Shareholder Value). One of the factors that influence Sustainable Shareholder Value is supply chain management. A well-managed supply chain would generate revenue and profit. Based on the aforementioned description, Ki Hadjar Dewantara Leadership Modeling was conducted on Sustainable Shareholder Value mediated by IT - Business Strategy Alignment on Integrated Supply Chain Management in the Pupuk Indonesia Group.

The novelty of this research is KHD Leadership development. It is the development of Javanese leadership concepts inherent in Indonesian society. The KHD leadership concept is believed to be applicable in Indonesian business and industrial organizations. The novelty of this research positioned new ideas in the form of developing the Ki Hadjar Dewantara Leadership concept and the renewal of the variable relationship in Sustainable Shareholder Value model/concept development.

\section{Literature Review}

\subsection{Leadership Theory}

Leadership is a process in which individuals influence groups to achieve common goals (Northouse, 2003: 3). This understanding was further explored by Dubrin. Leadership is the ability to instill confidence and obtain support from members of the organization to achieve organizational goals (Dubrin, 2001: 3). Leadership exists within a leader or manager. The characteristic aspects were distinguished into leader characteristics and manager characteristics. Luthans (2002: 576) described the characteristics of leaders in the XXI Century as follows: Innovates; Original; Develops; Focuses on people; Inspires trust; Long-range perspective; Asks what and why; Eye on the horizon; Originates; Challenges the Status quo; Own person; Does the right thing. A leader who are highly educated are more knowledgeable with better cognitive ability (Altuwaijri \& Kalyanaraman, 2020).

The Republic of Indonesia is a nation rich in creation, idea, and resources. These are not inferior to other nations. The Republic of Indonesia creations and ideas are recognized globally. Regarding leadership intentions/ideas, Indonesia possess a deep leadership philosophy adhering to cultural values and is embraced by the Indonesian. The philosophy is described in three Javanese proverb: "Ing Ngarsa Sung Tuladha, Ing Madya Mangun Karsa, Tut Wuri Handayani" (Kusmanto \& Widodo, 2016; Marce \& Purbonuswanto, 2019; Marliani \& Djadjuli, 2019).

Ki Hadjar Dewantara, Father of Indonesian Education, created this philosophy when he founded Taman Siswa as a place of learning for natives during the Dutch colonial period. Initially, this philosophy was aimed at educators to be able to inspire, set an example, and encourage their students. However, this philosophy is relevant to be applied in the Indonesian business organization. In reality, a leader is a teacher figure who educates students. According to Kusmanto \& Widodo (2016), Marce \& Purbonuswanto (2019) and Marliani \& Djadjuli, (2019), the following are the three basic principles (trilogy) of Ki Hadjar Dewantara leadership, namely:

\subsubsection{Ing Ngarso Sung Tulodo}

The sentence "Ing Ngarso Sung Tulodo" means to set an example in the front. A leader is a person seen by all the people they lead. Therefore, a leader must be able to be an example and a guide. They set examples for the subordinates. A leader does not merely govern in the front line. A leader must be able to set an example and be responsible for achieving the planned shared vision. 


\subsubsection{Ing Madyo Mangun Karso}

The sentence "Ing Madyo Mangun Karso" means inspires enthusiasm in the middle. A leader must be able to establish solidarity and motivate to achieve goals. A leader must be able to embrace the people they lead, willing to accept criticism and suggestions, and inspire enthusiasm to achieve a shared vision. Leaders must be able to the creative positive organizational atmosphere. It would encourage the organization members to motivate each other and achieve desired goals.

\subsubsection{Tut Wuri Handayani}

The sentence "Tut Wuri Handayani" means encourage from behind. A leader positioned in the back row does not necessarily mean they hide behind followers or being cowards. It should be interpreted as encouraging the subordinates to express, create, initiate, and build confidence. The subordinates would be inspired to be independent. In addition, it would encourage the subordinates to work hard, instead of merely adhering to superiors orders. A leader must be able to put themselves behind to encourage individuals to improve themselves and achieve goals. Leaders are expected to be able to educate and develop subordinates. In turn, it would form the subordinates into new generation leaders. A good leader is someone capable to nurture better leaders for the future generation.

\subsection{IT and Business Strategy Alignment Theory}

Business strategy is an essential point in wading through competition and even innovation itself, including procedures in increasing competition (Firman et. al., 2020). IT - Business Strategy Alignment is a business process in which alignment strategies are crucial to align information technology and business activities. According to Chao and Chandra (2012), IT - Business Strategy Alignment is a knowledge-based ability to allocate and use IT resources accordingly to achieve business and IT strategy alignment. A good view of IT knowledge and its influence on aligning IT - business strategies is an important element and improves company competitive advantage. Henderi et al. (2010) stated that IT management acts as a means to align IT and business. It is needed to explain the new role of IT in organizations, measure the contribution of each organization component, determine the influence and benefits of IT investments, decision making, and obtaining a better project. Panda and Rath (2018) stated that business alignment strategies reflect efficient coordination between IT and business (non-IT) activities to improve business processes and create increased business value. According to Henderi et al. (2010), IT management possess 5 focus which is described as follows:

\section{Strategic Alignment}

Focusing on ensuring business relationships and IT plans, defining, maintaining, and validating the value of IT propositions, and aligning IT operations with company operations (compatibility of IT operations with company operations).

\section{Value Delivery}

Implement a value proposition throughout the delivery cycle, ensure that IT provides benefits on the strategy, concentrate on optimizing costs, and proving the intrinsic value of IT.

\section{Resource Management}

Focus on optimal investment, good management, critical IT resources: applications, information, infrastructure, and users / human resources. Critical issues related to knowledge and infrastructure optimization.

\section{Risk Management}

Requires senior company officials risk awareness, clear understanding of risk appetite, compliance requirements, transparency on significant risks to the company, and instilling risk management responsibilities in the organization.

\section{Performance Measurement}

Track and monitor strategy implementation, project completion, use of resources, performance, and service processes. For instance, using a balanced scorecard that translates strategies into actions to achieve measurable goals beyond conventional accounting.

\subsection{Integrated Supply Chain Management Theory}

The current business sector continues competing to meet increasing consumer needs. In addition, the consumer gradually gains knowledge in determining needs. Great strategic management implementation explicitly determines firms' outcome and consequences (Phornlaphatrachakorn \& Peemanee, 2020). Every company endeavors to improve productivity, efficiency, speed, ease of service. Furthermore, companies continue to create a variety of innovations to prevail and survive in the market. Pujawan and Mahendrawati (2010) explained that suppliers, manufacturers, distributors, retailers, and customers possess a crucial role in creating cheap, high-quality, and fast products. In turn, it encouraged the development of the Supply Chain Management concept.

Supply Chain is a series of activities covering the functions of the company. It ranges from raw material procurement, product manufacturing, product distribution, and delivery. In order to operate efficiently, these functions must operate in an integrated manner. Providing fast and quality responses to the supply chain require the coordination of various functions throughout the company. The supply chain management function operates at three levels: strategic, tactical, and operational level (Fox et al., 1993). Lummus and Vokurka (1999) stated that the supply chain is all activities involved in shipping products from raw materials procurement to product delivery to customers. It covers raw materials and parts procurement, manufacturing and assembly, warehouse and inventory tracking, order entry and order management, channel distribution, and delivery. Furthermore, information systems are crucial to monitor all these activities. 
Supply Chain Management coordinates and integrates the activities into a seamless process. It connects organization internal departments and external partners including suppliers, operators, third party companies, and information system providers. Integrated Supply Chain Management (ISCM) consists of a set of agents working in a collaborative manner. Each agent performs one or more supply chain management functions and coordinates its decisions with other relevant agents. There are two types of agents: functional agents and information agents (Fox et al., 1993). Functional agents plan and / or control activities in the supply chain. Information agents support other agents by providing information and communication services.

\subsection{Sustainable Shareholder Value Theory}

Sustainability has become a concern in the discourse of globalization in relation to company performance. Sustainability is a controversial issue and possesses various definitions. Until recently there is no standard definition of sustainability, especially in the company context. Therefore, the measurement and interpretation of the construct depend on the goals and interests of the researchers.

The definition of sustainability associated to Triple Bottom Line (TBL) perspective is described as follows: "TBL sustainability as the result of the activities of an organization, voluntary or governed by law, that demonstrates the ability of an organization to maintain the viability of its business operations (including financial viability as appropriate ) while not negatively impacting any social or ecological systems'. (Smith \& Sharicz, 2011).

Company sustainability covers several aspects, one of which is the sustainability aspect of the company shareholders. There are several business terms known as stakeholder, shareholder, or stockholder. According to Budimanta et al. (2008), stakeholders are individuals, groups of people, communities, as a whole or in a partial manner, possessing relationships and interests in the company. Individuals, groups, communities are concerned stakeholders should they possess power, legitimacy, and interests in the company. Stakeholders are defined as individuals and groups who are affected by the achievement of organizational goals and in turn can influence the achievement of these goals (Freeman \& Medoff, 1985). According to Biset (1998), stakeholders are people with an interest or attention to a problem.

Shareholders or stockholders have financial shares in the company. On the other hand, stakeholders may or may not have an interest in the company financial matters. Shareholders may act as stakeholders. However, stakeholders are not part of the shareholders. Shareholders are directly affected by the company, while stakeholders are indirectly or directly affected. Stakeholders have responsibilities and influence on the company, while shareholders are only affected party. Shareholders own part of the company, while not all stakeholders own part of the company.
Shareholders are the main stakeholders and stockholders of the company. Stakeholders are parties concerned about the financial and other company matter. Stakeholders are employees, staff, customers, suppliers, and families of the employees. Shareholders are investors and stockholders of a company. However, there are organizations possessing stakeholders forgoing shareholders. One example of the aforementioned organization is a university. A university organization does not own shares. University stakeholders are lecturers, students, administrators, and staff. Aras \& Crowther study (2008); Høgevold et al. (2015); Padin et al. (2016) divided Sustainable Shareholder Value into two indicators, namely:

1) General Triple Bottom Line is the economic, social, environmental performance and business practices ability achieved by the organization.

2) Specific Triple Bottom Line is business sustainability performance and ability run by the organization.

Shareholder Theory states that a company most fundamental responsibility is to increase shareholders value. Furthermore, Shareholder Theory states that company management and shareholders work in a collaborative manner to increase the company value. Management carries out various activities aimed to increase profits and minimize losses for company shareholders. The company should pay attention to the interests of suppliers, customers, employees, and the environment especially when shareholders value decreases. Therefore, company management must consider the interests of shareholders to ensure long term company sustainability. It includes increasing shareholder value (Smerdon in Sutedi, 2011). Therefore, most companies prioritize the interests of shareholders rather than the employees, customers, suppliers, and the environment.

Company management must be able to manage company resources in the form of employees (human capital), physical assets (physical capital), and structural capital to create company value. Managing and utilizing company resources create added company value and improves financial performance. All activities are carried out in the interests of shareholders. Based on the aforementioned description, Sustainable Shareholder is the ability possessed by shareholders (company shareholders) in increasing company value continuously.

\section{Research Methodology}

This research used a quantitative approach, in which the analysis was carried out on numerical data measuring variable results. The variables studied were 3P-KHD Leadership, IT - Business Strategy Alignment, Integrated Supply Chain Management, and Sustainable Shareholder Value. The variable used was a latent variable measured using a research instrument in the form of a questionnaire. The research data was employee perception. Furthermore, the research data were analyzed using the statistical method, namely structural equation modeling (SEM). 


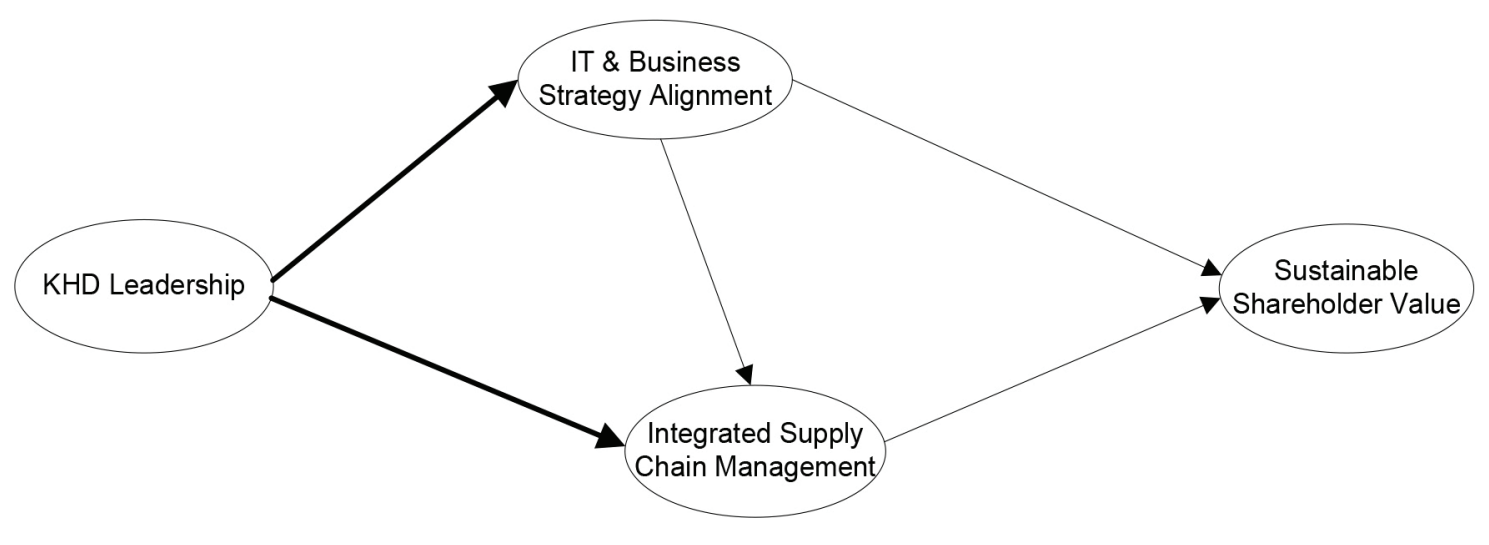

Figure 1: Research Model

The population in this study were all echelon 1,2 , and 3 employees at PT Pupuk Indonesia Holding Company and PT Pupuk Indonesia Group subsidiaries (Pupuk Kaltim, Pupuk Petro Kimia Gresik, Pupuk Pusri, Pupuk Kujang, Pupuk Iskandar Muda). The total population was $\mathrm{N}=1002$ individuals. The total sample was 300 echelon 1, 2, and 3 employees of PT Pupuk Indonesia Holding Company and the Pupuk Indonesia Group subsidiaries. The sample determination was conducted in a random manner through the lottery. The sample framework was a list of all employees at each level. The lottery draw was conducted by making paper rolls according to the sample frame. One roll was taken in a random manner and recorded. The process was repeated until the sample determination reached the sample size at each stratum. The following is the conceptual framework of this research.

Research Hypothesis:

H1: 3P-KHD Leadership influences IT - Business Strategy Alignment

H2: 3P-KHD Leadership influences Integrated Supply Chain Management

H3: IT - Business Strategy Alignment influences Integrated Supply Chain Management

H4: IT - Business Strategy Alignment influences Sustainable Shareholder Value

H5: Integrated Supply Chain Management influences Sustainable Shareholder Value

\section{Results and Discussion}

\subsection{Measurement Model}

This research utilized the reflective measurement model. The outer model possesses a loading value that functions to exhibit the weight of each indicator as a measure of each latent variable. The indicator with the largest outer loading exhibits that the indicator is the strongest (dominant) variable gauge.
Based on Table 1, the implementation of KHD Leadership in Pupuk Indonesia Group is related to the three pillars (indicators) of Ing Ngarsa Sung Tuladha, Ing Madya Mangun Karsa, and Tut Wuri Handayani, relatively in a balanced condition. This was exhibited through the relatively similar loading value (around 0.41). The leaders at Pupuk Indonesia Group have applied these three pillars equally and proportionally, in the initial stage (Ing Ngarsa Sung Tuladha), in the work implementation (Ing Madya Mangun Karsa), and at the finished stage (Tut Wuri Handayani ).

Product Oriented Strategic Alignment strongly influence the IT - Business Strategy Alignment variable. This exhibits that Product Oriented Strategic Alignment is the most important aspect of IT - Business Strategy Alignment development and implementation. Product Oriented Strategic Alignment indicator is described as follows: (1) Systematic exploration of production ideas, (2) Creation of new product ideas utilizing IT resources, (3) Implementation of new product marketing strategies aligned with IT, (4) IT support in the production process, and (5) Optimization of new product development strategies. Pupuk Indonesia Group is a manufacturing company, therefore the production aspect is crucial.

The Integrated Supply Chain Management variable possesses two crucial indicators, namely Strategic Supplier Partnership and Customer Relationship. PT Pupuk Indonesia Holding Company Integrated Supply Chain development and implementation are focused on suppliers and customers. However, the Integrated Supply Chain works in tandem as exhibited through the relatively small loading value.

The Sustainable Shareholder Value (Y3) variable exhibited that General Triple Bottom Line (Y3.1) and Specific Triple Bottom Line (Y3.2) indicators possess a similar weight of 0.553 with $p$-value $<0.001$. Therefore both indicators are a significant measure of Sustainable Shareholder Value (Y3). Based on the aforementioned description, the General Triple Bottom Line (Y3.1) and the Specific Triple Bottom Line (Y3.2), have the same degree of strength in reflecting Sustainable Shareholder Value in the PT Pupuk Indonesia Group. This indicates a good relationship between the shareholders and the company, especially from the perspective of Sustainable Value. 
Tabel 1: Evaluation of measurement models

\begin{tabular}{|c|c|c|c|}
\hline Variable & Indicators & Loading & p-value \\
\hline \multirow[t]{3}{*}{ KHD Leadership (X) } & Ing Ngarsa Sung Tulada (X1) & 0.406 & $<0.001$ \\
\hline & Ing Madya Mangun Karsa (X2) & 0.409 & $<0.001$ \\
\hline & Tut Wuri Handayani (X3) & 0.406 & $<0.001$ \\
\hline \multirow{3}{*}{$\begin{array}{l}\text { IT \& Business Strategy } \\
\text { Alignment (Y1) }\end{array}$} & Product Oriented Strategic Alignment (Y1.1) & 0.418 & $<0.001$ \\
\hline & Quality Oriented Strategic Alignment (Y1.2) & 0.399 & $<0.001$ \\
\hline & Market Oriented Strategic Alignment (Y1.3) & 0.404 & $<0.001$ \\
\hline \multirow{5}{*}{$\begin{array}{l}\text { Integrated Supply Chain } \\
\text { Management (Y2) }\end{array}$} & Strategic Supplier Partnership (Y2.1) & 0.290 & $<0.001$ \\
\hline & Customer Relationship (Y2.2) & 0.290 & $<0.001$ \\
\hline & Level of Information Sharing (Y2.3) & 0.277 & $<0.001$ \\
\hline & Quality of Information Sharing (Y2.4) & 0.269 & $<0.001$ \\
\hline & Postponement (Y2.5) & 0.281 & $<0.001$ \\
\hline \multirow{2}{*}{$\begin{array}{l}\text { Sustainable Shareholder } \\
\text { Value (Y3) }\end{array}$} & Triple Bottom Line Umum (Y3.1) & 0.553 & $<0.001$ \\
\hline & $\begin{array}{l}\text { Triple Bottom Line Khusus (Environmental, } \\
\text { Economic, Social) (Y3.2) }\end{array}$ & 0.553 & $<0.001$ \\
\hline
\end{tabular}

Tabel 2: SEM Analysis Direct Effect

\begin{tabular}{|c|c|c|c|c|c|}
\hline \multicolumn{3}{|c|}{ Influence between Latent variables } & \multirow{2}{*}{$\begin{array}{l}\text { Coefficient } \\
\text { value }\end{array}$} & \multirow{2}{*}{ P-value } & \multirow{2}{*}{ Kesimpulan } \\
\hline Var. The cause & $\rightarrow$ & Var. As a result & & & \\
\hline KHD Leadership & $\mathrm{H} 1$ & $\begin{array}{l}\text { IT \& Business Strategy } \\
\text { Alignment }\end{array}$ & $0.229^{* * *}$ & $<0.001$ & Significant \\
\hline KHD Leadership & $\mathrm{H} 2$ & $\begin{array}{l}\text { Integrated Supply Chain } \\
\text { Management }\end{array}$ & $0.244^{\star * *}$ & $<0.001$ & Significant \\
\hline $\begin{array}{l}\text { IT \& Business Strategy } \\
\text { Alignment }\end{array}$ & H3 & $\begin{array}{l}\text { Integrated Supply Chain } \\
\text { Management }\end{array}$ & $0.235^{\star \star \star}$ & $<0.001$ & Significant \\
\hline $\begin{array}{l}\text { IT \& Business Strategy } \\
\text { Alignment }\end{array}$ & H4 & Sustainable Shareholder Value & $0.149^{\star * \star}$ & 0.004 & Significant \\
\hline $\begin{array}{l}\text { Integrated Supply Chain } \\
\text { Management }\end{array}$ & H5 & Sustainable Shareholder Value & $0.197^{\star \star *}$ & $<0.001$ & Significant \\
\hline
\end{tabular}

\subsection{SEM Analysis}

The path coefficient states the strength of the relationship between one variable to another. The higher coefficient indicates an increasingly stronger influence. On the other hand, negative or positive signs indicate the direction of the relationship. Whether it is in the same direction or opposite direction. P-value $<0.05$ indicates a variable significant influence on other variables. SEM-
WarpPLS possess two influence, namely direct effect, an indirect effect. The direct influence test result is presented in Table 2.

The Influence of KHD Leadership on IT - Business Strategy Alignment. Hypothesis one (H1) is accepted. The research result exhibited the path coefficient value of 0.229 and $\mathrm{p}$-value $<0.001$. It indicates a significant positive effect. The precise implementation of KHD Leadership improves IT - Business Strategy Alignment. 
Satriyo NUGROHO, Umar NIMRAN, Mochammad Al MUSADIEQ, Solimun SOLIMUN /

Table 3: SEM Analysis Indirect Effect

\begin{tabular}{|l|l|l|c|c|c|}
\hline \multicolumn{2}{|l|}{ Influence between Latent variables } & \multirow{2}{*}{$\begin{array}{c}\text { Coefficient } \\
\text { value }\end{array}$} & P-value & Conclusion \\
\cline { 1 - 2 } Var. The cause & \multicolumn{1}{|c|}{ Var. As a result } & $0.054^{*}$ & 0.092 & Significant \\
\hline KHD Leadership & $\begin{array}{l}\text { IT \& Business } \\
\text { Strategy Alignment }\end{array}$ & $\begin{array}{l}\text { Integrated Supply } \\
\text { Chain Management }\end{array}$ & 0.076 & Significant \\
\hline KHD Leadership & $\begin{array}{l}\text { Integrated Supply } \\
\text { Chain Management }\end{array}$ & $\begin{array}{l}\text { Sustainable } \\
\text { Shareholder Value }\end{array}$ & $0.048^{*}$ & 0.127 & insignificant \\
\hline $\begin{array}{l}\text { IT \& Business Strategy } \\
\text { Alignment }\end{array}$ & $\begin{array}{l}\text { Integrated Supply } \\
\text { Chain Management }\end{array}$ & $\begin{array}{l}\text { Sustainable } \\
\text { Shareholder Value }\end{array}$ & $0.046^{\mathrm{ns}}$ & & \\
\hline
\end{tabular}

The Influence of KHD Leadership on Integrated Supply Chain Management. Hypothesis two (H2) is accepted. Research result exhibited path coefficient value of 0.244 and $\mathrm{p}$-value $<0.001$. It indicates a significant positive effect. The precise implementation of KHD Leadership increases the Integrated Supply Chain Management variable.

The influence of IT - Business Strategy Alignment on Integrated Supply Chain Management. Hypothesis three (H3) was accepted. The research result exhibited a path coefficient of 0.234 with a p-value of $<0.001$. IT - Business Strategy Alignment variable has a significant positive effect on the Integrated Supply Chain Management variable. It indicates that higher IT - Business Strategy Alignment variable increases the Integrated Supply Chain Management variable.

The influence of IT - Business Strategy Alignment on Sustainable Shareholder Value. Hypothesis four (H4) is accepted. The analysis result exhibited path coefficient value 0.149 and a p-value $0.004<0.05$. It indicates a significant positive direct effect of the IT - Business Strategy Alignment variable on the Sustainable Shareholder Value variable. Better IT - Business Strategy Alignment increases Sustainable Shareholder Value.

The influence of Integrated Supply Chain Management on Sustainable Shareholder Value variables. Hypothesis five (H5) is accepted. The analysis result exhibited a path coefficient value of 0.197 and a $p$-value $<0.001$. It indicates that Integrated Supply Chain Management has a significant positive effect on Sustainable Shareholder Value. Better Integrated Supply Chain Management increases Sustainable Shareholder Value.

The indirect effect of KHD Leadership on Integrated Supply Chain Management (Y2) mediated by IT - Business Strategy Alignment (Y1), exhibited the coefficient of indirect effect 0.054 and $\mathrm{p}$-value $=0.092$ (weakly significant). It indicates a significant indirect effect of KHD Leadership (X) on Integrated Supply Chain Management mediated by IT - Business Strategy Alignment (Y1). KHD Leadership variable possesses a direct effect on Integrated Supply Chain Management and an indirect effect through IT - Business Strategy Alignment. It indicates that IT - Business Strategy Alignment is a mediating variable.
The indirect effect of KHD Leadership on Sustainable Shareholder Value mediated by Integrated Supply Chain Management exhibited an indirect effect coefficient of 0.048 and p-value $=0.076$ (weakly significant). It indicates KHD leadership have significant indirect effect on Sustainable Shareholder Value mediated by Integrated Supply Chain Management. The research analysis exhibited that the KHD Leadership variable indirectly affects the Sustainable Shareholder Value mediated by Integrated Supply Chain Management. It indicates that the Integrated Supply Chain Management variable is a mediating variable.

The indirect effect of IT - Business Strategy Alignment on Sustainable Shareholder Value (Y3) mediated by Integrated Supply Chain Management, exhibited indirect effect coefficient 0.046 and $p$-value $=0.127$ (not significant). The IT - Business Strategy Alignment variable directly affect Sustainable Shareholder Value without Integrated Supply Chain Management mediation. Therefore, Integrated Supply Chain Management is not a mediating variable.

\subsection{Importance Performance Analysis (IPA)}

The IPA exhibits the position of each item of the research variable in the priority concept. The IPA was measured using loading factor as the importance level and the average empirical score as the perceived level of performance. The IPA analysis result is presented in a cartersius diagram.

Based on Figure 2, the indicator Ing Ngarsa Sung Tuludo / set an example in the front (X1.1), Ing Madya Mangun Karsa / inspire enthusiasm in the middle (X1.2), and Tut Wuri Handayani / encourages from behind (X1.3) are in quadrant IV. This exhibits that the indicators possess very good performance in determining employee perceptions related to Ki Hadjar Dewantara Leadership practices at PT Pupuk Indonesia Holding Company. However, Pupuk Indonesia Group employees do not pay attention to these indicators. PT Pupuk Indonesia Holding Company, PT Pupuk Kaltim, PT Pupuk Petrokima, PT Pupuk Kujang, PT Pupuk Sriwidjaja, and PT Pupuk Iskandar Muda need to maintain the leadership performance and prioritize improving $\mathrm{Ki}$ Hadjar Dewantara leadership practices in the company. 


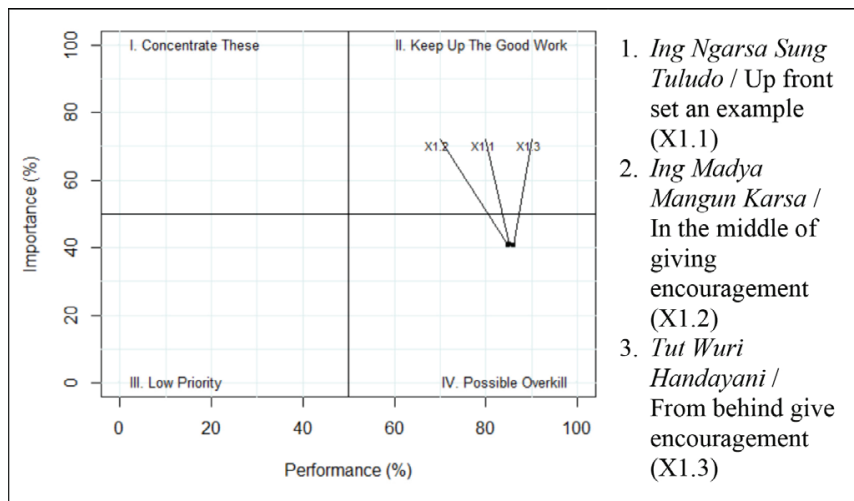

Figure 2: IPA Analysis for KHD Leadership Variable

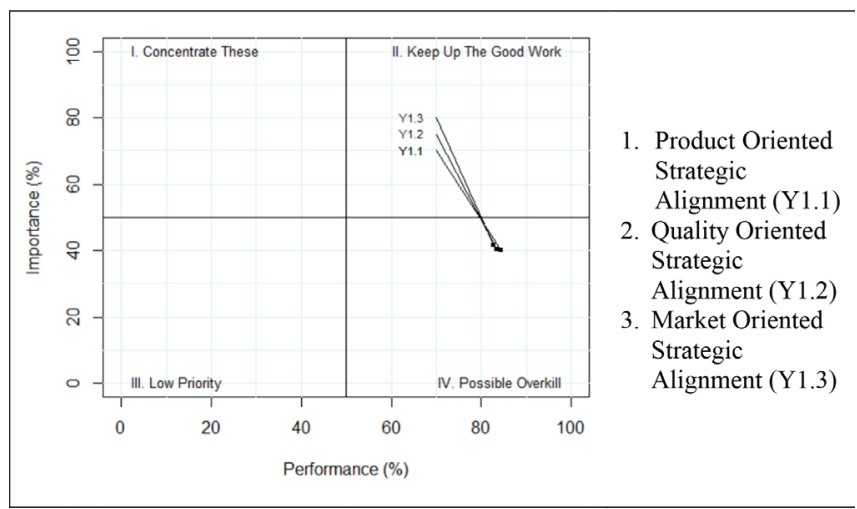

Figure 3: IPA Analysis for IT \& Business Strategy Alignment Variable

Based on Figure 3, Product Oriented Strategic Alignment (Y1.1), Quality Oriented Strategic Alignment (Y1.2), and Market Oriented Strategic Alignment (Y1.3) are in quadrant IV. This exhibits that Pupuk Indonesia Group employees pay less attention to the practice of IT - Business Strategy Alignment. IT - Business Strategy Alignment indicators exhibited very good performance at the PT Pupuk Indonesia Holding Company. PT Pupuk Indonesia Holding Company, PT Pupuk Kaltim, PT Pupuk Petrokima, PT Pupuk Kujang, PT Pupuk Sriwidjaja, and PT Pupuk Iskandar Muda need to maintain and improve IT - Business Strategy Alignment performance.

Based on Figure 3, Strategic Supplier Partnership (Y2.1), Customer Relationship (Y2.2), Level of Information Sharing (Y2.3), Quality of Information Sharing (Y2.4), and Postponement (Y2.5) indicators are in quadrant IV. This exhibits that these indicators have very good performance in determining employee perceptions related to Integrated Supply Chain Management practices at PT Pupuk Indonesia Holding Company. However,

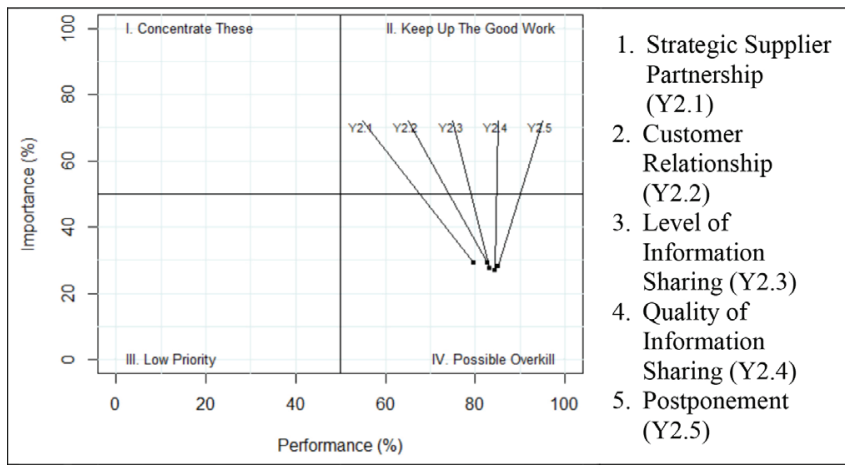

Figure 4: IPA Analysis for Integrated Supply Chain Management

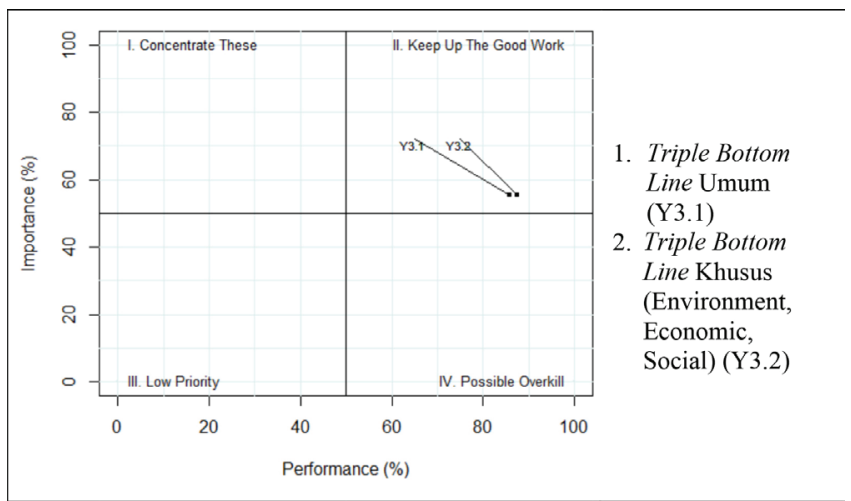

Figure 5: IPA Analysis for Sustainable Shareholder Value Variable

Pupuk Indonesia Group employees pay less attention to these indicators. PT Pupuk Indonesia Holding Company, PT Pupuk Kaltim, PT Pupuk Petrokima, PT Pupuk Kujang, PT Pupuk Sriwidjaja, and PT Pupuk Iskandar Muda need to maintain Integrated Practice Supply Chain Management performance. Furthermore, Pupuk Indonesia Group need to prioritize improving Integrated Practice Supply Chain Management practices.

Based on Figure 4, the General Triple Bottom Line (Y3.1) and the Special Triple Bottom Line (Environment, Economic, Social) (Y3.2) are in quadrant II. This exhibits that these indicators are crucial indicators in determining employee perceptions related to Sustainable Shareholder Value at the Pupuk Indonesia Group. In addition, the indicators exhibit good performance. PT Pupuk Indonesia Holding Company, PT Pupuk Kaltim, PT Pupuk Petrokima, PT Pupuk Kujang, PT Pupuk Sriwidjaja, and PT Pupuk Iskandar Muda need to maintain the Sustainable Shareholder Value and improve General Triple Bottom Line and Specific Triple Bottom Line performance in the company. 


\subsection{Discussion}

Based on hypothesis testing, KHD Leadership has a significant positive effect on IT - Business Strategy Alignment. It indicates that high level of KHD Leadership (Ki Hadjar Dewantara Leadership) increases IT - Business Strategy Alignment in six Pupuk Indonesia Group companies namely, PT Pupuk Indonesia Holding Company, PT Pupuk Kalimantan Timur, PT Pupuk Petrokimia Gresik, PT Pupuk Sriwidjaja Palembang, PT Pupuk Kujang Cikampek, and PT Pupuk Iskandar Muda. The research result is in line with Shao (2018), Hickman \& Akdere (2017), Zarrabi \& Vahedi (2012), Schoemaker \& Krupp (2015), and Palladan et al. (2016). KHD Leadership is an underdeveloped concept, especially in the international context. The similarity of the research result and the previous study indicates that this research produced a new concept. The previous study used different leadership concepts compared to this research.

The implementation of the Ki Hadjar Dewantara Trilogy concept is able to encourage subordinates, create a vision of the future, and develop strategies to achieve company goals, especially IT - Business Strategy Alignment. IT - Business Strategy Alignment is a business process in which alignment strategies are needed to align information technology with business activities. The achievement of IT - Business Strategy Alignment requires a sustainable effort based on appropriate strategic planning (Chen, 2010). Alignment between IT and business strategy has been identified as an important antecedent for increasing company profitability and achieving competitive advantage (Chan et al., 2006; Pearlson \& Saunders, 2012). The synergy between the two strategies is crucial. Panda and Rath (2018) stated that IT - Business Strategy Alignment reflects efficient coordination between IT and business activities to create better company value.

The hypothesis assessment exhibited that KHD Leadership have significant positive influence on Integrated Supply Chain Management. It indicates that high level of KHD Leadership (Ki Hadjar Dewantara Leadership) increases Integrated Supply Chain Management in six Pupuk Indonesia Group companies namely, PT Pupuk Indonesia Holding Company, PT Pupuk Kalimantan Timur, PT Pupuk Petrokimia Gresik, PT Pupuk Sriwidjaja Palembang, PT Pupuk Kujang Cikampek, and PT Pupuk Iskandar Muda. The research result is in line with Dubey et al. (2014), Williams et al. (2020), Hult et al. (2007), and Birasnav (2002).

Based on the research result, the Pupuk Indonesia Group needs to increase the role of all parties in creating cheap, high-quality, and fast products. This process encouraged a new concept namely Integrated Supply Chain Management (Pujiawan \& Mahendrawati, 2010). Supply Chain is a series of activities covering the functions of a company. It involves raw material procurement, product manufacturing, distribution, and delivery. In order to operate efficiently, these functions must operate in an integrated manner. Providing fast and quality responses to supply chain events require the coordination of various functions throughout the company. The supply chain management function operates at three levels: strategic, tactical, and operational level (Fox et al., 1993). Integrated Supply Chain Management coordinates and integrates all these activities into a seamless process. It connects organization internal departments and external partners including suppliers, operators, third party companies, and information system providers.

The SEM-WarpPLS analysis result exhibit that high level of IT - Business Strategy Alignment increases Integrated Supply Chain Management at PT Pupuk Indonesia Holding Company. Information technology supports the organization internal operations and collaboration between companies in the supply chain. By utilizing high-speed data networks and databases, companies can share data to manage the supply chain as a whole and part of the supply chain. The concept of the supply chain has become a popular operating paradigm. IT - Business Strategy Alignment, in the form of strategic, tactical, and operational levels, can manage supply chain management operations (Fox et al., 1993). There is a significant relationship between strategy and supply chain management (Hoejmose et al., 2013).

IT - Business Strategy Alignment is a business process requires alignment strategy to align information technology with business activities. Achieving IT - Business Alignment requires a sustainable effort based on appropriate strategic planning (Chen, 2010). Alignment between IT and business strategy has been identified as an important antecedent for increasing company profitability and achieving competitive advantage (Chan et al., 2006; Pearlson \& Saunders, 2012). The synergy between the two strategies is crucial. On the one hand, IT strategies must be formulated and implemented in accordance with the business vision, objectives, and operational processes. Furthermore, the spread and implementation of IT strategies may affect business strategies. Therefore, it is necessary to maintain coordination and balance between the two strategies.

IT - Business Strategy Alignment and Integrated Supply Chain Management have a significant positive effect on Sustainable Shareholder Value. According to Fabozzi \& Drake (2009), Shareholder Value is most often associated with the net present value of the estimated cash flow attributed to the owner of the company. In addition, Rappaport (1986) argues that shareholder value is driven by the level of sales growth, operating profit margins, additional capital investment, income tax, and capital costs. However, according to Walters (1997), sustainable shareholder value could be achieved by implementing various corporate strategies. For instance, customer loyalty management, financial gearing, corporate control, and innovation capacity. 
In addition to financial drivers, there are factors influencing shareholder value, namely customer relations, product innovation, customized products, employee skills (Kaplan \& Norton, 2003). Bistrova et al. (2014) stated that sustainable shareholder value is based on long-term and stable economic performance, in addition to a well-implemented corporate governance system, high CSR standards, rational capital budgeting, and high financial accountability. Bistrova \& Lace (2012) proposed that the Sustainable Shareholder Value model is good corporate governance offering highincome quality, high innovation potential, and optimal capital structure to ensure low capital costs.

Based on the aforementioned shareholder value concept, other variables influencing Sustainable Shareholder Value are Corporate Governance, Strategic Investment, Capital Management, Earning Quality, Financial Results, Stakeholders, Corporate Social Responsibilities, and other variables. These factors represent the economic performance of a company.

\section{Conclusion}

Based on the analysis result, KHD Leadership empirically has a significant positive effect on IT - Business Strategy Alignment and Integrated Supply Chain Management. In addition, IT - Business Strategy Alignment and Integrated Supply Chain Management have a significant positive effect on Sustainable Shareholder Value. Pupuk Indonesia Group companies (PT Pupuk Indonesia Holding Company, PT Pupuk Kalimantan Timur, PT Pupuk Kujang Cikampek, PT Petrokimia Gresik, PT Pupuk Sriwidjaja Palembang, and PT Pupuk Iskandar Muda) need to pay attention to the role of leaders, especially leaders capable to enforce Ki Hadjar Dewantara Trilogy concept to increase Sustainable Shareholder Value. In addition, carrying out IT - Business Strategy practices and Supply Chain Management simultaneously in an integrated manner from production to marketing process may increase Sustainable Shareholder Value.

\section{References}

Altuwaijri, B. M., \& Kalyanaraman, L. (2020). CEO EducationPerformance Relationship: Evidence from Saudi Arabia. Journal of Asian Finance, Economics and Business, 7(8), 259-268.

Aras, G., \& Crowther, D. (2008). Governance and sustainability: An investigation into the relationship between corporate governance and corporate sustainability. Management Decision, 46(3), 433-448.

Bain, J. S. (1956). Barriers to new competition, their character and consequences in manufacturing industries, Cambridge, MA: Harvard University Press.

Bain, J. S. (1968). Industrial Organization. New York, NY: John Willey \& Sons.
Bartek, J., \& Lukas, J. (2001). Mammalian G1-and S-phase checkpoints in response to DNA damage. Current Opinion in Cell Biology, 13(6), 738-747.

Budimanta, A., Prasetijo, A., \& Rudito, B. (2008). Corporate Social Responsibility. Jakarta, Indonesia: ICSD.

Chao, C. A., \& Chandra, A. (2012). Impact of owner's knowledge of information technology (IT) on strategic alignment and IT adoption in US small firms. Journal of Small Business and Enterprise Development, 19(1), 114-131.

Chen, M. J. (1996). Competitor analysis and interfirm rivalry: Toward a theoretical integration. Academy of Management Review, 21(1), 100-134.

Gimeno, J., \& Woo, C. Y. (1996). Hypercompetition in a multimarket environment: The role of strategic similarity and multimarket contact in competitive de-escalation. Organization Science, 7(3), 322-341.

Daggett, T. L., Pearce, C. M., Tingley, M., Robinson, S. M. C., \& Chopin, T. (2005). Effect of prepared and macroalgal diets and seed stock source on somatic growth of juvenile green sea urchins. Aquaculture, 244(1-4), 263-281.

DuBrin, A. J. (2001). Human relations for career and personal success. New York, NY: Pearson College Division.

Firman, A., Putra, A. H. P. K., Mustapa, Z., Ilyas, G. B., \& Karim, K. (2020). Re-conceptualization of Business Model for Marketing Nowadays: Theory and Implications. Journal of Asian Finance, Economics, and Business, 7(7), 279-291. https://doi.org/10.13106/jafeb.2020.vol7.no7.279

Fox, M. S., Chionglo, J. F., \& Barbuceanu, M. (1993). The integrated supply chain management system. Technical Report, Department of Industrial Engineering, University of Toronto.

Freeman, R. B., \& Medoff, J. L. (1985). What do unions do. Industrial and Labor Relations Review, 38(2), 244-263. https://doi.org/10.1177/001979398503800207

Henderi, H., Nuraeni, Y., Junaidi, J., \& Hidayat, R. (2010). It Governance: A Strategic Alignment for Information Technology/Business. CCIT Journal, 4(1), 57-69.

Høgevold, N. M., Svensson, G., Klopper, H. B., Wagner, B., Valera, J. C. S., Padin, C., Ferro, C., \& Petzer, D. (2015). A triple bottom line construct and reasons for implementing sustainable business practices in companies and their business networks. Corporate Governance, 15(4), 427-443. https://doi. org/10.1108/CG-11-2014-0134

Hoskisson, R. E., Wan, W. P., Yiu, D., \& Hitt, M. A. (1999). Theory and research in strategic management: Swings of a pendulum. Journal of Management, 25(3), 417-456.

Hoskisson, R. E., Yiu, D., \& Kim, H. (2004). Corporate governance systems: Effects of capital and labor market congruency on corporate innovation and global competitiveness. The Journal of High Technology Management Research, 15(2), 293-315.

Hunger, J. D., \& Wheelen, T. L. (2003), Essentials of Strategic Management. Upper Saddle River, NJ: Prentice Hall. 
Kartono, K. (1998). Leader and leadership: what is an abnormal leader?. Jakarta, Indonesia: PT. Raja Grafindo Persada.

Kasmir, S. E. (2006). Entrepreneurship. Jakarta, Indonesia: PT. Raja Grafindo Persada.

Kusmanto, B. \& Widodo, S. A. (2016). Ki Hadjar Dewantara's Leadership Pattern. Jurnal Managemen Pendidikan, 11(2), 1907-4034.

Lummus, R. R., \& Vokurka, R. J. (1999). Defining supply chain management: a historical perspective and practical guidelines. Industrial Management \& Data Systems, 99(1), 11-17.

Luthans, F. (2002). The need for and meaning of positive organizational behavior. Journal of Organizational Behavior: The International Journal of Industrial, Occupational and Organizational Psychology and Behavior, 23(6), 695-706.

Mamduh, M. H., \& Halim, A. (2003). Financial statement analysis. Yogyakarta, Indonesia: YKPN.

Marce, T. D., \& Purbonuswanto, W. (2019). Ki Hadjar Dewantara's Leadership Implementation in Practical Learning Management. Media Manajemen Pendidikan, 2(1), 146. [Indonesian]

Marliani, L., \& Djadjuli, R. D. (2019). Measuring the Trilogy of $\mathrm{Ki}$ Hadjar Dewantara's Leadership in the Era of Globalization. Kebijakan: Jurnal Ilmu Administrasi, 10(2), 74-80.

Mason, E. S. (1939). Price and production policies of large-scale enterprise. The American Economic Review, 29(1), 61-74.

Northouse, P. G. (2004). Leadership: Theory and practice. Thousand Oaks, CA: Sage Publications.

Padin, C., Ferro, C., Wagner, B., Valera, J. C. S., Høgevold, N. M., \& Svensson, G. (2016). Validating a triple bottom line construct and reasons for implementing sustainable business practices in companies and their business networks. Corporate Governance: The International Journal of Business in Society, 16(5), 849-865.

Panda, S., \& Rath, S. K. (2018). Strategic IT-business alignment and organizational agility: from a developing country perspective. Journal of Asia Business Studies, 12(4), 422-440.
Park, S. H., \& Luo, Y. (2001). Guanxi and organizational dynamics: Organizational networking in Chinese firms. Strategic Management Journal, 22(5), 455-477.

Phornlaphatrachakorn, K., \& Peemanee, J. (2020). Integrated Performance Measurement as a Strategic Management Accounting Approach: A Case of Beverage Businesses in Thailand. Journal of Asian Finance, Economics and Business, 7(8), 247-257. https://doi.org/10.13106/jafeb.2020.vol7.no8.247

Porter, M. F. (1980). An algorithm for suffix stripping. Program: Electronic Library and Information Systems, 14(3), 130-137.

Porter, M. E., \& Millar, V. E. (1985). How information gives you competitive advantage. Harvard Business Review, 63(4), 149-160.

Porter, M. E. (1996). Competitive advantage, agglomeration economies, and regional policy. International Regional Science Review, 19(1-2), 85-90.

Nyoman, P. I., \& Mahendrawathi, E. R. (2010). Supply Chain Management. Surabaya, Indonesia: Guna Widya.

Simamora, H. (2000). Accounting Basis for Business Decision Making. Jakarta, Indonesia: Salemba Empat.

Smith, P. A., \& Sharicz, C. (2011). The shift needed for sustainability. The Learning Organization: An International Journal, 18(1), 73-86.

Spanos, Y. E., \& Lioukas, S. (2001). An examination into the causal logic of rent generation: contrasting Porter's competitive strategy framework and the resource-based perspective. Strategic Management Journal, 22(10), 907-934.

Stahl dan Grigsby, D. W. (1992). Strategic Management for Decision Making. Boston, MA: PWS-KENT Publishing Company.

Sutedi, A. (2011). Good corporate governance. Jakarta, Indonesia: Sinar Grafika.

Tan, J., \& Litschert, T. W. (1994). Ownership types and strategic groups in emerging economies. The Journal of Management Studies, 41(2004), 1105-1129.

Venkatraman, N. (1989). The concept of fit in strategy research: Toward verbal and statistical correspondence. Academy of Management Review, 14(3), 423-444. 